\title{
Oats and CVD risk markers: a systematic literature review
}

\author{
Frank Thies $^{1 *}$, Lindsey F. Masson ${ }^{2,3}$, Paolo Boffetta ${ }^{4,5}$ and Penny Kris-Etherton ${ }^{6}$ \\ ${ }^{1}$ Division of Applied Medicine, University of Aberdeen, Polwarth Building, Foresterbill, Aberdeen AB25 2ZD, Scotland, UK \\ ${ }^{2}$ Division of Applied Health Sciences, University of Aberdeen, Polwarth Building, Foresterbill, Aberdeen AB25 2ZD, \\ Scotland, UK \\ ${ }^{3}$ School of Pharmacy and Life Sciences, Robert Gordon University, Riverside East, Garthdee Road, Aberdeen AB10 $7 G J$, \\ Scotland, UK \\ ${ }^{4}$ The Tisch Cancer Institute and Institute for Translational Epidemiology, Icabn School of Medicine at Mount Sinai, \\ New York, NY 10029, USA \\ ${ }^{5}$ International Prevention Research Institute, 69006 Lyon, France \\ ${ }^{6}$ Department of Nutritional Sciences, Pennsylvania State University, University Park, PA 16802, USA
}

(Submitted 4 October 2013 - Final revision received 27 May 2014 - Accepted 17 June 2014)

\section{Abstract}

High consumption of whole-grain food such as oats is associated with a reduced risk of CVD and type 2 diabetes. The present study aimed to systematically review the literature describing long-term intervention studies that investigated the effects of oats or oat bran on CVD risk factors. The literature search was conducted using Embase, Medline and the Cochrane library, which identified 654 potential articles. Seventy-six articles describing sixty-nine studies met the inclusion criteria. Most studies lacked statistical power to detect a significant effect of oats on any of the risk factors considered: $59 \%$ of studies had less than thirty subjects in the oat intervention group. Out of sixty-four studies that assessed systemic lipid markers, thirty-seven (58\%) and thirty-four (49\%) showed a significant reduction in total cholesterol (2-19\% reduction) and LDL-cholesterol (4-23\% reduction) respectively, mostly in hypercholesterolaemic subjects. Few studies (three and five, respectively) described significant effects on HDL-cholesterol and TAG concentrations. Only three out of twenty-five studies found a reduction in blood pressure after oat consumption. None of the few studies that measured markers of insulin sensitivity and inflammation found any effect after long-term oat consumption. Long-term dietary intake of oats or oat bran has a beneficial effect on blood cholesterol. However, there is no evidence that it favourably modulates insulin sensitivity. It is still unclear whether increased oat consumption significantly affects other risk markers for CVD risk, and comprehensive, adequately powered and controlled intervention trials are required to address this question.

\section{Key words: Oats: CVD: Risk markers: Cholesterol: Inflammation: Insulin sensitivity}

High consumption of whole-grain foods is associated with a reduced risk of chronic diseases including $\mathrm{CHD}^{(1,2)}$, hypertension $^{(3)}$ and type 2 diabetes $^{(4,5)}$. Suggested mechanisms of action include reduction in serum lipid concentrations ${ }^{(6)}$ and blood pressure ${ }^{(7)}$, increased insulin sensitivity ${ }^{(8)}$ and reduction in thrombotic and inflammatory markers ${ }^{(9,10)}$. However, the results of the two most comprehensive, well-designed randomised control trials ever conducted with whole-grain foods found no significant effects on the major risk factors for $\mathrm{CVD}^{(7,11)}$.

Whole grains consumed in a western diet consist mainly of wheat, rye, maize and oats. These cereals have different chemical compositions, which could explain the different responses with regard to CVD risk markers. Research has focused on $\beta$-glucan-rich cereals such as oats for their potential effect on serum cholesterol concentration ${ }^{(12)}$ and postprandial glycaemia ${ }^{(13)}$, with inconsistent results.
Although numerous studies suggest that there is a beneficial effect of oat consumption on markers of CVD risk, there is a need for a rigorous assessment of the strength of this evidence. The present study aimed to systematically review the literature describing intervention studies that had investigated the effect of regular consumption of whole-grain oat-based products (including oat bran) on risk factors for CVD. The objectives of the study were (i) to summarise the extensive literature on the subject, (ii) to describe the relative strengths and weaknesses of the studies and (iii) to evaluate the need for large intervention trials.

\section{Methods}

\section{Literature search and study selection}

The methods for the present literature review have been previously described (Thies F, Masson LF, Boffetta $\mathrm{P}$ et al., 
in this supplement). Briefly, Embase, Medline and the Cochrane library (Cochrane Central Register of Controlled Trials) were searched for articles describing intervention studies with oat-based products published before 26 November 2012. A total of 1174 articles were identified (Fig. 1). Titles and abstracts of 654 articles were reviewed independently by two reviewers who agreed that the full text should be obtained for 244 articles. A further 178 articles were then excluded, following agreement by two reviewers. Ten additional articles were identified by searching the reference lists in relevant articles obtained from the database search.

\section{Data extraction}

Data were extracted by one reviewer into pre-prepared tables and the data extraction from a random $10 \%$ of articles was checked and agreed by a second reviewer. The primary outcomes of interest included blood lipids/lipoproteins, blood pressure, glucose and insulin.

\section{Quality of reporting and reporting preferences}

Use of the Jadad scale for reporting randomised control trials ${ }^{(14)}$ to score the quality of reporting of each article, as well as the criteria for classifying studies as randomised control trials, is described elsewhere (Thies F, Masson LF, Boffetta $\mathrm{P}$ et al., in this supplement). For studies that showed a statistically significant $(P<0.05)$ effect of oats consumption, the percentage change from baseline in the intervention group relative to the control group was the preferred measure to present. If this was not available in the article, it was calculated from the results given, and such values are indicated in the tables. Interventions that involved products with altered molecular weight of $\beta$-glucan were not included.

\section{Results}

\section{Study characteristics}

We identified seventy-six articles ${ }^{(7,15-89)}$ describing sixty-nine studies that assessed the effect of oat consumption on CVD

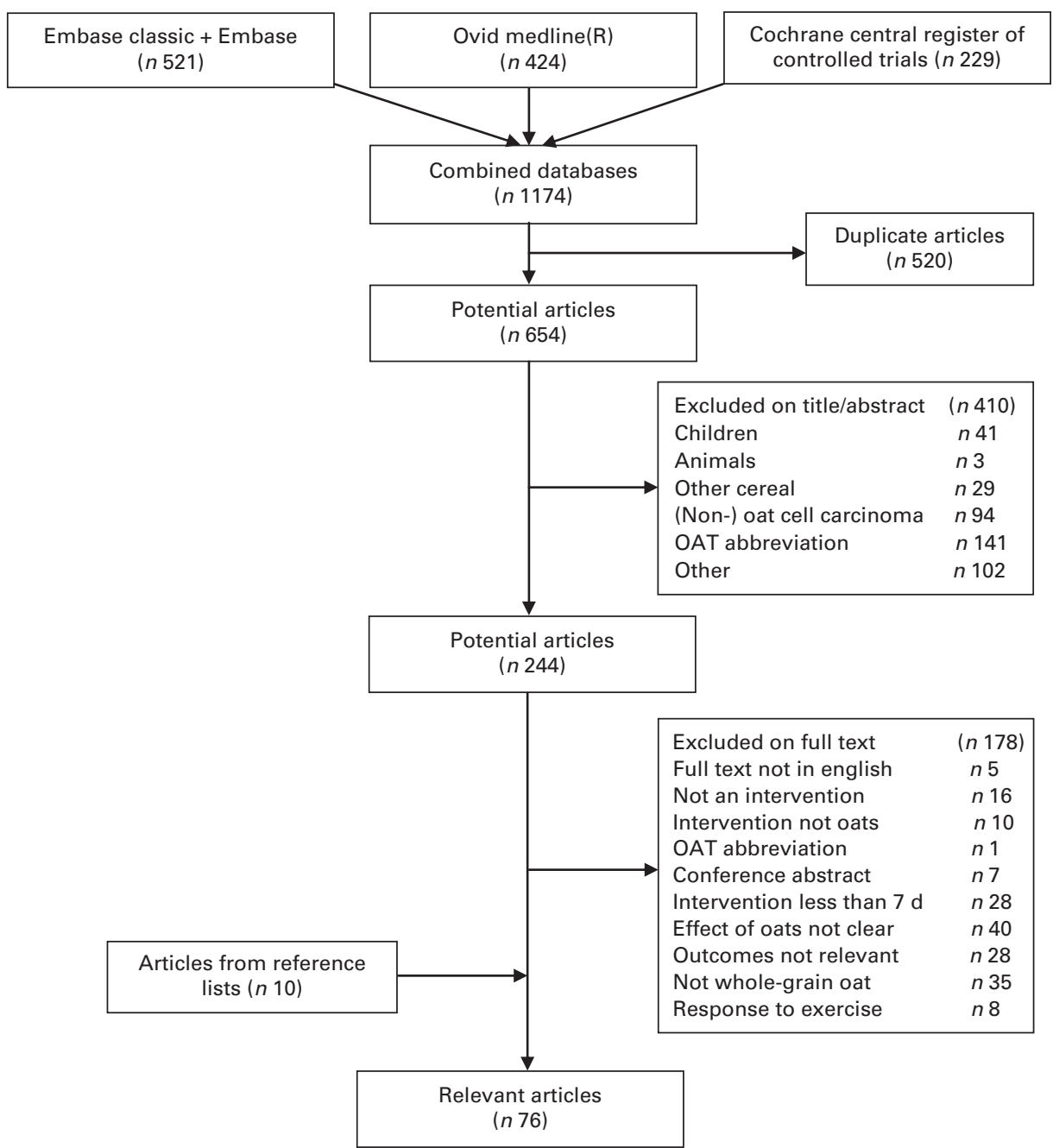

Fig. 1. Flow diagram of article selection. 
risk factors (Fig. 1). Online Web Tables S1-S3 describe the characteristics of these sixty-nine studies with less than thirty subjects (forty-one studies, 59\%), between thirty and fifty-nine subjects (seventeen studies, 25\%), and at least sixty subjects (eleven studies, 16\%) in the oat intervention group, respectively. These tables are sub-grouped according to the quality of reporting of the articles: forty-six articles (61\%) had a low quality of reporting, and thirty articles (39\%) had a high quality of reporting.

Over half $(54 \%)$ of the studies were carried out in North America (thirty-four in the USA and three in Canada). Six studies were carried out in Australia, five in Sweden, four each in the UK and New Zealand, three in Finland, two in the Netherlands, and one each in Austria, France, Germany, Denmark, China, Mexico and Brazil. One multicentre study was carried out in sites in Canada, the UK and Australia.

\section{Lipids}

Tables 1-3 show the results of sixty-four studies that assessed the blood lipid response to oat intervention in studies with less than thirty subjects, thirty to fifty-nine subjects or at least sixty subjects, respectively, in the oat intervention group. Of these sixty-four studies, thirty-seven (58\%) and thirty-four $(53 \%)$ studies identified a statistically significant reduction in total cholesterol and LDL-cholesterol, respectively, mostly in hypercholesterolaemic subjects; the rest of the studies found no significant response. This significant reduction ranged from 2 to $19 \%$ for total cholesterol and from 4 to $23 \%$ for LDL-cholesterol. In the eleven studies that contained at least sixty subjects in the oat intervention group, a higher proportion of studies found significant reductions in total cholesterol and LDL-cholesterol (eight studies (73\%) and seven studies (64\%), respectively), but the magnitude of these reductions was more conservative: $3-6 \%$ for total cholesterol and $4-8 \%$ for LDL-cholesterol (Table 3).

Three studies found that oat consumption significantly increased HDL-cholesterol levels by $4-11 \%$. The ratios of total cholesterol:HDL-cholesterol and of LDL-cholesterol: HDL-cholesterol were reduced significantly in three studies (by $2-7 \%$ ) and in five studies (by 9-21\%), respectively. Five studies found a statistically significant reduction in TAG concentrations (by 11-24\%) following oat-based intervention.

There is currently no evidence that oat consumption influences concentrations of $\mathrm{HDL}_{2}$ and $\mathrm{HDL}_{3}$ subfractions $^{(18,45,49,83)}$, intermediary density lipoprotein (IDL) cholesterol $^{(18)}$, VLDL cholesterol ${ }^{(15,18,23,24,33,41,42,57,62,87)}$, or LDL, HDL or VLDL particle size ${ }^{(49)}$.

\section{Blood pressure}

Table 4 shows that three ${ }^{(41,55,75)}$ of twenty-five studies found that oat consumption significantly reduced systolic blood pressure by $4-6 \%$. Two of these studies ${ }^{(41,55)}$ had less than thirty subjects in the oat intervention group. Pins et al. ${ }^{(75)}$ found that $73 \%$ of participants receiving treatment for hypertension were able to stop or reduce their medication by one-half after 6 weeks of consuming oats compared with $42 \%$ in the wheat-based cereal (control) group $(P<0.05)$. In addition, participants in the oat intervention group whose medication was not reduced had a significant $4 \%$ decrease in systolic blood pressure in comparison with the control group. The other twenty-two studies found no significant effect of oat consumption on systolic blood pressure.

\section{Glucose and insulin}

Blood glucose levels changed significantly in response to oat consumption in five out of twenty-one studies (Table 5). Glucose levels increased in three ${ }^{(37,51,59)}$ of these studies relative to the comparison group or baseline, and glucose levels decreased in the other two studies ${ }^{(52,75)}$. Four of these five studies had less than thirty subjects in the oat intervention group, and the other study, with $n 45$ in the oat intervention group, found a $13 \%$ decrease in glucose after 12 weeks of an oat-rich diet compared with the control group who consumed wheat cereals ${ }^{(75)}$.

Fifteen out of sixteen studies found no significant effect of oats on insulin concentrations. One relatively small study with twenty-two participants found that high-molecular weight oat bran significantly increased insulin concentrations by $23 \%$ compared with baseline ${ }^{(52)}$. None of the studies that measured glucose:insulin ratio ${ }^{(51)}$, HbA1c ${ }^{(15,35)}$, homeostasis model assessment ${ }^{(7,41,66)}$, quantitative insulin sensitivity check index (QUICKI) ${ }^{(7)}$, insulin sensitivity ${ }^{(41,49,50,55)}$ or the acute insulin response to glucose ${ }^{(49)}$ found a significant effect of oat consumption on these variables. One study found that glucose effectiveness decreased in the oat intervention group by $5 \%$ but increased in the wheat intervention group by $19 \%(P=0.03 \text { for interaction })^{(49)}$.

\section{Other outcomes}

None of the studies that measured C-reactive $\operatorname{protein}^{(7,25,44,77,82,88)}$, lipoprotein(a) $(\operatorname{Lp}(\mathrm{a}))^{(28,79)}$, fibrinogen ${ }^{(20)}$ or IL-6 $6^{(7)}$ found a significant effect of oat consumption on these variables. There is also a lack of evidence for a beneficial effect of oats on endothelial function ${ }^{(70-72)}$.

One study ${ }^{(44)}$ reported measuring plasma homocysteine and found that concentrations were reduced by $16 \%$ in response to 12 weeks of oat bran. A Danish study found that plasminogen activator inhibitor-I and factor VII levels decreased significantly by 27 and 7\%, respectively, following a 2-week oat bran $v$. a low-fibre $\operatorname{diet}^{(33)}$, but no other studies reported measuring these outcomes. Another study measured serum NEFA that increased by $19 \%$ after consuming $35-50 \mathrm{~g} / \mathrm{d}$ of oat bran for 4 weeks, relative to the group consuming an oat bran-free diet ${ }^{(79)}$.

\section{Discussion}

\section{Lipids/lipoproteins}

The present systematic review supports the results of observational studies suggesting that increased oat consumption 
Table 1. Oats and blood lipids (studies with $<30$ subjects in the oat intervention group)

\begin{tabular}{|c|c|c|c|c|c|c|c|}
\hline \multirow[b]{2}{*}{ Comparison } & \multicolumn{5}{|c|}{ Cholesterol } & \multirow[b]{2}{*}{ TAG } & \multirow[b]{2}{*}{ Reference } \\
\hline & Total & LDL & HDL & Total:HDL & LDL:HDL & & \\
\hline \multicolumn{8}{|l|}{ Low reporting quality } \\
\hline Oat bran $v$. wheat bran & NS & NS & NS & - & NS & NS & Abrahamsson et al. ${ }^{(15)}$ \\
\hline $100 \mathrm{~g} / \mathrm{d}$ oat bran $v$. control diet & $19 \% \downarrow$ & $23 \% \downarrow$ & NS & - & - & $19 \%{ }^{*} \downarrow$ & Anderson et al. ${ }^{(16)}$ \\
\hline $25 \mathrm{~g} / \mathrm{d}$ oat bran $v$. baseline & $5 \% \downarrow$ & $9 \% \downarrow$ & NS & - & - & NS & Anderson et al. ${ }^{(17)}$ \\
\hline Oat bran $v$. wheat bran & $8 \% \%^{*} \downarrow$ & $7 \% \%^{*} \downarrow$ & NS & - & NS & NS & $\begin{array}{l}\text { Anderson et al. } .^{(18)} \\
\text { Bridges et al. }\end{array}$ \\
\hline Oat bran $v$. wheat bran bread & NS & NS & NS & - & - & NS & Bremer et al. ${ }^{(20)}$ \\
\hline $28 \mathrm{~g} / \mathrm{d}$ oatmeal $v .28 \mathrm{~g} / \mathrm{d}$ farina & NS & NS & NS & - & _- & NS & Davidson et al. ${ }^{(21)}$ \\
\hline $28 \mathrm{~g} / \mathrm{d}$ oat bran $v .28 \mathrm{~g} / \mathrm{d}$ farina & NS & NS & NS & - & - & NS & \\
\hline $56 \mathrm{~g} / \mathrm{d}$ oatmeal $v .28 \mathrm{~g} / \mathrm{d}$ farina & NS & NS & NS & - & - & NS & \\
\hline $56 \mathrm{~g} / \mathrm{d}$ oat bran $v .28 \mathrm{~g} / \mathrm{d}$ farina & $10 \% * \downarrow$ & $17 \% * \downarrow$ & NS & - & - & NS & \\
\hline $84 \mathrm{~g} / \mathrm{d}$ oatmeal $v .28 \mathrm{~g} / \mathrm{d}$ farina & $8 \%{ }^{*} \downarrow$ & $11 \%^{*} \downarrow$ & NS & - & - & NS & \\
\hline $84 \mathrm{~g} / \mathrm{d}$ oat bran $v .28 \mathrm{~g} / \mathrm{d}$ farina & $8 \% * \downarrow$ & $12 \% * \downarrow$ & NS & - & - & NS & \\
\hline $\begin{array}{l}\text { LFLC } v \text {. LFLC and oat bran } \\
v \text {. oat bran } v \text {. processed oat bran }\end{array}$ & NS & - & NS & NS & - & - & $\begin{array}{l}\text { Demark-Wahnefried } \\
\text { et al. }\end{array}$ \\
\hline $50 \mathrm{~g} / \mathrm{d}$ oat bran $v$. baseline & $12 \% \downarrow$ & - & - & $7 \% \%^{*} \downarrow$ & - & - & \\
\hline $40 \mathrm{~g} / \mathrm{d}$ oat bran $v$. low-fibre diet & NS & NS & NS & - & - & NS & Dubois et al. \\
\hline $100 \mathrm{~g} / \mathrm{d}$ oat bran $v$. rice bran & NS & NS & NS & - & NS & NS & Hegsted et al. ${ }^{(24)}$ \\
\hline Oat bran bread $v$. strawberries & NS & NS & NS & NS & - & NS & Jenkins et al. ${ }^{(25)}$ \\
\hline $125 \mathrm{~g} / \mathrm{d}$ rolled oats $v$. control diet & NS & - & NS & - & - & NS & Judd \& Truswell(26) \\
\hline $\begin{array}{l}\text { Oat bran muffins (immediate) } \\
\text { v. no oat bran muffins }\end{array}$ & NS & NS & NS & NS & - & - & Kahn et al. ${ }^{(27)}$ \\
\hline $100 \mathrm{~g} / \mathrm{d}$ oat bran $v$. baseline & $8 \% \downarrow$ & $10 \% \downarrow$ & NS & - & - & NS & Kelley et al. ${ }^{(28)}$ \\
\hline Oat $v$. wheat (bread and cookies) & NS & NS & NS & NS & - & NS & Kerckhoffs et al. (29) \\
\hline Oat $v$. wheat (orange juice) & $4 \% \downarrow$ & $7 \% \downarrow$ & NS & $5 \% \downarrow$ & - & NS & \\
\hline $100 \mathrm{~g} / \mathrm{d}$ oat bran $v$. baseline & $13 \% \downarrow$ & $14 \% \downarrow$ & NS & - & - & NS & Kirby et al. ${ }^{(30)}$ \\
\hline Toasted oat bran $v$. control & NS & - & - & - & - & NS & $\begin{array}{l}\text { Kretsch et al. }{ }^{(31)} \\
\quad \text { Calloway \& Kretsch } \\
\end{array}$ \\
\hline Untoasted oat bran $v$. control & NS & - & - & - & - & NS & \\
\hline Oat bran $v$. low-fibre diet & $10 \%^{*} \downarrow$ & NS & NS & - & - & $12 \%^{*} \downarrow$ & Kristensen \& Bugel ${ }^{(33)}$ \\
\hline Oat-based cereal $v$. wheat cereal & NS & NS & NS & - & - & NS & Maki et al. ${ }^{(34)}$ \\
\hline $100 \mathrm{~g} / \mathrm{d}$ oat bran $v$. low-fibre diet & $9 \% \%^{*} \downarrow$ & - & - & - & _- & NS & Marlett et al. ${ }^{(36)}$ \\
\hline Oat bran v. high-amylose starch & NS & NS & NS & - & - & $11 \%^{*} \downarrow$ & Noakes et al. ${ }^{(37)}$ \\
\hline Oat bran $v$. low-amylose starch & NS & NS & NS & - & - & $16 \%$ $\downarrow$ & \\
\hline $0.75-1 \mathrm{l} / \mathrm{d}$ oat milk $v$. cow's milk & NS & NS & NS & - & - & NS & Onning et al. ${ }^{(38)}$ \\
\hline $0.75-1 \mathrm{l} / \mathrm{d}$ oat milk $v$. soya milk & NS & NS & NS & - & - & NS & \\
\hline $28 \mathrm{~g} / \mathrm{d}$ oat bran $v$. no supplement & NS & NS & $9 \% * \uparrow$ & NS & NS & NS & Robitaille et al. ${ }^{(39)}$ \\
\hline Oat bran $v$. wheat bran & $18 \%^{*} \downarrow$ & $22 \%{ }^{*} \downarrow$ & NS & - & $14 \%{ }^{*} \downarrow$ & NS & Romero et al. ${ }^{(40)}$ \\
\hline Oat bran v. psyllium & NS & NS & NS & - & NS & NS & \\
\hline $45 \mathrm{~g} / \mathrm{d}$ oats $v$. without $45 \mathrm{~g} / \mathrm{d}$ oats & $10 \%$ * & $12 \%^{*} \downarrow$ & NS & - & - & NS & Saltzman et al. ${ }^{(41)}$ \\
\hline $77 \mathrm{~g} / \mathrm{d}$ oat bran $v$. baseline & $6 \% \downarrow$ & $7 \%^{*} \downarrow$ & NS & - & - & - & Spiller et al. ${ }^{(42)}$ \\
\hline $77 \mathrm{~g} / \mathrm{d}$ oat bran $v .15 \mathrm{~g} / \mathrm{d}$ guar gum & $5 \% * \uparrow$ & $11 \%{ }^{*} \uparrow$ & NS & - & - & NS & \\
\hline $50 \mathrm{~g} / \mathrm{d}$ oat bran or oat-free diet & NS & NS & - & - & - & NS & Stewart et al. ${ }^{(43)}$ \\
\hline $150 \mathrm{~g} / \mathrm{d}$ rolled oats $v$. baseline & $5 \%^{*} \downarrow$ & $14 \% \downarrow$ & NS & - & - & NS & Turnbull \& Leeds ${ }^{(45)}$ \\
\hline Oat bran $v$. wheat bran & $4 \% \downarrow$ & $6 \% \downarrow$ & NS & - & - & NS & Whyte et al. ${ }^{(46)}$ \\
\hline Oat bran $v$. wheat flour & $9 \% \downarrow$ & $12 \% \downarrow$ & NS & - & - & NS & Zhang et al. ${ }^{(47)}$ \\
\hline \multicolumn{8}{|l|}{ High reporting quality } \\
\hline $\begin{array}{l}5-6 \mathrm{~g} / \mathrm{d} \text { oat bran } \beta \text {-glucan } v .8-9 \mathrm{~g} / \mathrm{d} \\
\text { oat bran } \beta \text {-glucan } v \text {. high fibre, } \\
\text { no oat bran } \beta \text {-glucan }\end{array}$ & NS & NS & NS & - & - & NS & Beck et al. ${ }^{(48)}$ \\
\hline Oatmeal and oat bran $v$. wheat-based cereal & NS & $11 \%{ }^{*} \downarrow$ & NS & NS & $21 \%{ }^{*} \downarrow$ & NS & Davy et al. ${ }^{(49,50)}$ \\
\hline $60 \mathrm{~g} / \mathrm{d}$ oat cookies $v$. baseline & NS & - & - & - & - & NS & $\begin{array}{l}\text { Conceicao } \\
\text { de Oliveira et al. } .^{(51)}\end{array}$ \\
\hline High MW oat bran $v$. baseline & NS & NS & NS & - & NS & NS & Frank et al. ${ }^{(52)}$ \\
\hline Low MW oat bran $v$. baseline & NS & NS & NS & - & NS & NS & \\
\hline $84 \mathrm{~g} / \mathrm{d}$ oat bran $v$. rice starch & $13 \%^{*} \downarrow$ & $13 \%^{*} \downarrow$ & NS & - & $14 \%^{*} \downarrow$ & NS & Gerhardt \& Gallo(53) \\
\hline $84 \mathrm{~g} / \mathrm{d}$ oat bran $v$. rice bran & NS & NS & NS & - & NS & NS & \\
\hline $\begin{array}{l}34 \mathrm{~g} / \mathrm{d} \text { oat bran } v \text {. wheat bran and whole- } \\
\text { wheat flour or wheat bran, whole-wheat } \\
\text { flour and } 17 \mathrm{~g} / \mathrm{d} \text { oat bran combined }\end{array}$ & $5 \% \%^{*} \downarrow$ & NS & NS & - & - & $15 \%^{*} \downarrow$ & Gold \& Davidson ${ }^{(54)}$ \\
\hline Oat cereal $v$. low fibre cereal & $11 \%{ }^{*} \downarrow$ & $18 \%{ }^{*} \downarrow$ & NS & - & - & NS & Keenan et al. ${ }^{(55)}$ \\
\hline Oat bran $v$. wheat bran & $6 \% \downarrow$ & $7 \% \%^{*}$ & NS & - & - & NS & Kestin et al. ${ }^{(56)}$ \\
\hline Oat bran $v$. rice bran & $4 \% \downarrow$ & $5 \%{ }^{*} \downarrow$ & NS & - & - & NS & \\
\hline $100 \mathrm{~g} / \mathrm{d}$ oat bran $v$. refined wheat & NS & NS & NS & - & - & - & Swain et al. ${ }^{(57)}$ \\
\hline $50 \mathrm{~g} / \mathrm{d}$ oat bran $v$. baseline & NS & NS & NS & - & - & NS & Uusitupa et al. ${ }^{(58,59)}$ \\
\hline
\end{tabular}

LFLC, low-fat, low-cholesterol diet; MW, molecular weight.

$\star \%$ change from baseline relative to comparison group estimated. 
Table 2. Oats and blood lipids (studies with thirty to fifty-nine subjects in the oat intervention group)

\begin{tabular}{|c|c|c|c|c|c|c|c|}
\hline \multirow[b]{2}{*}{ Comparison } & \multicolumn{5}{|c|}{ Cholesterol } & \multirow[b]{2}{*}{ TAG } & \multirow[b]{2}{*}{ Reference } \\
\hline & Total & LDL & $\mathrm{HDL}$ & Total:HDL & LDL:HDL & & \\
\hline \multicolumn{8}{|l|}{ Low reporting quality } \\
\hline Kilned oats $v$. baseline $(A) \dagger$ & NS & - & NS & - & - & NS & Kemppainen et al. ${ }^{(60)}$ \\
\hline Unkilned oats $v$. baseline $(\mathrm{B})$ & NS & - & NS & - & - & $24 \%{ }^{*} \downarrow$ & \\
\hline 0 v. 30 v. 60 v. $90 \mathrm{~g} / \mathrm{d}$ oat bran & NS & NS & NS & - & - & - & Leadbetter et al. ${ }^{(61)}$ \\
\hline $55 \mathrm{~g}$ high-fibre oat bran $v$. run-in & NS & NS & $11 \%{ }^{*} \uparrow$ & - & $9 \% * \downarrow$ & NS & Mackay \& Ball ${ }^{(62)}$ \\
\hline $55 \mathrm{~g}$ low-fibre oat bran $v$. run-in & NS & NS & $11 \%$ $\uparrow$ & - & $10 \% * \downarrow$ & NS & \\
\hline Oat bran crispies $v$. no oat cereal & $2 \% \downarrow$ & $5 \% \downarrow$ & NS & NS & NS & NS & Poulter et al. ${ }^{(63)}$ \\
\hline $57 \mathrm{~g} / \mathrm{d}$ instant oats $v$. usual intake & $5 \% * \downarrow$ & $5 \% *$ & NS & - & - & NS & Van Horn et al. ${ }^{(64)}$ \\
\hline NCEP and oat bran $v$. NCEP & $6 \% * \downarrow$ & $9 \%^{*} \downarrow$ & NS & - & - & NS & Winblad et al. ${ }^{(65)}$ \\
\hline NCEP and oat bran $v$. washout & NS & $9 \%$ $\downarrow$ & NS & - & - & NS & \\
\hline \multicolumn{8}{|l|}{ High reporting quality } \\
\hline $\begin{array}{l}\text { Oats (high) } v \text {. oats, rice and wheat } \\
\text { (low) } v \text {. corn, rice and wheat bars }\end{array}$ & NS & NS & NS & NS & - & NS & Charlton et al..$^{(66)}$ \\
\hline Oat bran $v$. wheat bran & $6 \%{ }^{*} \downarrow$ & $9 \%{ }^{*} \downarrow$ & NS & - & - & NS & Kashtan et al. ${ }^{(68)}$ \\
\hline Uncooked whole oats $v$. baseline & $5 \% * \downarrow$ & $7 \%$ $\downarrow$ & NS & - & - & NS & Katz et al. ${ }^{(72)}$ \\
\hline Oatbran $v$. wheat bran & NS & $6 \%{ }^{*} \downarrow$ & NS & - & $9 \%{ }^{*} \downarrow$ & NS & Lepre \& Crane ${ }^{(73)}$ \\
\hline Oat milk $v$. rice milk & $6 \%^{*} \downarrow$ & $6 \% \%^{*} \downarrow$ & NS & - & NS & NS & Onning et al. ${ }^{(74)}$ \\
\hline $\begin{array}{l}\text { Oatmeal and Oat Squares } \\
v \text {. wheat cereal and Kellogg's Crispix }\end{array}$ & $11 \% \%^{*} \downarrow$ & $12 \%^{*} \downarrow$ & NS & - & - & NS & Pins et al. ${ }^{(75)}$ \\
\hline Muesli with oat $\beta$-glucan $v$. wheat fibre & $3 \% \downarrow$ & $5 \% \downarrow$ & NS & $2 \% \downarrow$ & - & NS & Theuwissen \& Mensink ${ }^{(76)}$ \\
\hline $\begin{array}{l}\text { Oats/soya and oats/milk } \\
\text { v. wheat/soya and wheat/milk }\end{array}$ & $4 \% * \downarrow$ & $6 \% \%^{*} \downarrow$ & NS & - & - & - & Van Horn et al. ${ }^{(78)}$ \\
\hline
\end{tabular}

NCEP, National Cholesterol Education Program.

*\% change from baseline relative to comparison group estimated.

† Group A started using kilned oats and group B started using unkilned oats.

has a beneficial effect on serum cholesterol concentration, particularly in hypercholesterolaemic subjects. This is consistent with Ripsin et al.'s ${ }^{(90)}$ rigorous meta-analysis that concluded that about $3 \mathrm{~g} / \mathrm{d}$ of soluble fibre from oat products can lower total cholesterol by 0.13 to $0.16 \mathrm{mmol} / \mathrm{l}$, with a greater reduction in individuals with higher initial cholesterol concentrations. A $1 \%$ reduction in total cholesterol or LDL-cholesterol is associated with a $2-3 \%$ or $1 \%$ decreased risk, respectively, of $\mathrm{CHD}^{(91)}$. The magnitude of the effect found in the present review $3-6 \%$ for total cholesterol and $4-8 \%$ for LDL-cholesterol when considering studies with a sufficient sample size) would translate to a $6-18 \%$ decrease in CHD risk, which would equate to a substantial health benefit at a population level. However, increased oat consumption does not seem to significantly benefit other systemic lipid/lipoprotein markers associated with CVD risk, such as serum TAG and HDL-cholesterol concentration.

Lipoprotein particle number and size, particularly for LDL, are possibly strong predictors of $\mathrm{CVD}^{(92)}$ and could provide an independent measure of atherogenicity, which may be superior to total cholesterol determination. However, only a few studies evaluated the effect of oat intervention on the size and concentration of lipoprotein particles, with inconclusive results. More evidence is needed to establish whether increased oat consumption favourably affects the lipoprotein particle profile.

\section{Blood pressure}

Few studies found a significant effect of increased oat consumption on blood pressure. However, none of the studies carried out to date was adequately powered to rigorously evaluate the effect of oats or oat bran on this outcome. Furthermore, blood pressure results from these studies were most likely averaged from only two or three consecutive measurements. Such methodology, recommended by the British Hypertension Society, might be useful to identify hypertensive subjects but does not represent a precise method for measuring blood pressure, as recently suggested ${ }^{(7)}$.

Tighe $e t a l .{ }^{(7)}$ found a significant reduction in systolic blood pressure after 12 weeks intervention with whole grain (wheat or oats plus wheat) compared with a refined cereals group. Blood pressure was measured using additional consecutive readings until the last three measurements varied by less than $8 \%$, and a significant reduction would not have been identified using the conventional method of measuring blood pressure. This demonstrates the requirement for all types of intervention trials (pharmaceutical, supplement, food-based, lifestyle interventions, etc.) where blood pressure is an outcome to adopt procedures designed to accurately measure blood pressure rather than those used for diagnostic classification. The best method to accurately measure blood pressure is to carry out 24-h ambulatory measurements. Thus, adequately powered and controlled intervention trials are required to determine the effects of oats on blood pressure.

\section{Glucose and insulin}

Impaired fasting glycaemia and impaired glucose tolerance are major risk factors for type 2 diabetes, and are strongly associated with an increased risk of CVD and all-cause mortality ${ }^{(93)}$. The present review indicates that interventions with oats or oat bran do not affect fasting glycaemia or insulin concentration. 
Table 3. Oats and blood lipids (studies with $\geq 60$ subjects in the oat intervention group)

\begin{tabular}{|c|c|c|c|c|c|c|c|}
\hline \multirow[b]{2}{*}{ Comparison } & \multicolumn{5}{|c|}{ Cholesterol } & \multirow[b]{2}{*}{ TAG } & \multirow[b]{2}{*}{ Reference } \\
\hline & Total & LDL & HDL & Total:HDL & LDL:HDL & & \\
\hline \multicolumn{8}{|l|}{ Low reporting quality } \\
\hline Oat bran $v$. no added oat bran & $4 \% * \downarrow$ & $6 \%{ }^{*} \downarrow$ & NS & - & - & NS & Berg et al. ${ }^{(79)}$ \\
\hline $90 \mathrm{~g} / \mathrm{d}$ oat cereal $v$. corn cereal & $6 \%{ }^{*} \downarrow$ & $8 \%{ }^{*} \downarrow$ & NS & - & - & NS & Karmally et al. ${ }^{(80)}$ \\
\hline Oat bran cereal and CNA $v$. CNA & NS & NS & NS & NS & - & NS & Keenan et al. ${ }^{(81)}$ \\
\hline Oat bran cereal $v$. baseline & NS & NS & NS & NS & - & NS & \\
\hline Oat cereal $v$. low-fibre foods & $3 \% \downarrow$ & $4 \% \downarrow$ & NS & - & - & NS & Maki et al. ${ }^{(82)}$ \\
\hline Whole-wheat foods and oats $v$. whole-wheat foods & NS & NS & NS & - & - & NS & Tighe et al. ${ }^{(7)}$ \\
\hline $56 \mathrm{~g}$ oatmeal or no oat products & NS & NS & NS & - & - & NS & Van Horn et al. ${ }^{(83)}$ \\
\hline $100 \mathrm{~g} / \mathrm{d}$ oatmeal $v$. wheat noodles & $4 \% \%^{*} \downarrow$ & $5 \%^{*} \downarrow$ & $4 \% \%^{*} \uparrow$ & - & - & NS & Zhang et al..$^{(84)}$ \\
\hline \multicolumn{8}{|l|}{ High reporting quality } \\
\hline $90 \mathrm{~g}$ oat cereal $v$. cornflakes & $4 \% \downarrow$ & $4 \% \downarrow$ & NS & - & - & NS & Johnston et al. ${ }^{(85)}$ \\
\hline Oat bran cereal $v$. wheat cereal & $6 \% \downarrow$ & $8 \% \downarrow$ & NS & - & - & - & Keenan et al. ${ }^{(86)}$ \\
\hline Oat bran $v$. no oat products & NS & - & - & - & - & - & Van Horn et al. ${ }^{(87)}$ \\
\hline Oatmeal $v$. no oat products & $3 \% \downarrow$ & - & - & - & - & - & \\
\hline Oat bran $v$. oatmeal $v$. no oat products & NS & NS & NS & - & - & NS & \\
\hline Oat bran $v$. wheat bran cereal & $4 \% \downarrow$ & $6 \% \downarrow$ & NS & NS & - & NS & Wolever et al. ${ }^{(88)}$ \\
\hline
\end{tabular}

CNA, controlled-release nicotinic acid

* $\%$ change from baseline relative to comparison group estimated.

Similarly, evidence to date suggests that markers for insulin resistance (homeostasis model assessment) or sensitivity that use algorithms including fasted glucose and insulin concentrations are also unchanged after intervention with oats or oat bran.

\section{Other outcomes}

Many inflammatory markers (including C-reactive protein, IL-6 and soluble intercellular adhesion molecule 1 (ICAM-1)) have been linked to CVD risk, but only high-sensitivity C-reactive protein is currently considered an independent marker of CVD risk ${ }^{(94)}$. Observational studies suggest that a high dietary fibre intake may reduce C-reactive protein levels ${ }^{(95,96)}$. However, only a few intervention studies reported the effect of long-term consumption of oats and oat bran on inflammatory markers or markers of endothelial dysfunction (von Willebrand factor, arterial stiffness and fibrinogen). None reported changes in these markers with increased oat consumption, suggesting that the benefits of oats on CVD are unlikely to be mediated by the modulation of these markers. However, more studies are needed to confirm the lack of effect, or otherwise, of oats on these putative markers.

Other systemic compounds that have been linked to an increased CVD risk include homocysteine ${ }^{(97)}$, plasminogen activator inhibitor- ${ }^{(98)}$ and factor VII ${ }^{(99)}$. However, the studies that examined the effects of increased oat consumption on these markers are scarce. One study reported measuring plasma homocysteine and found that concentrations decreased by $16 \%$ in response to 12 weeks of oat bran ${ }^{(44)}$. A Danish study ${ }^{(33)}$ found that plasminogen activator inhibitor-I and factor VII levels decreased significantly by 27 and $7 \%$, respectively, following a 2 -week oat bran $v$. a low-fibre diet. No other studies reported measuring these outcomes, which deserve further investigation.

Weight gain is associated with an increased risk of high blood pressure and hyperlipidaemia. Whilst some studies suggest that increased oat consumption may aid weight $\operatorname{loss}^{(16,69)}$ and reduce waist circumference ${ }^{(82,84)}$, the majority of studies reviewed herein found no significant effect of oat consumption on weight ${ }^{(15,17-20,22,24-26,28-30,33,36,38-40,42,45,48-50,52,55-58}$, $60-64,66-68,73-76,79,82-85,87,88)$, BMI ${ }^{(15,39-41,43,49,50,58,60,64,78,79,84)}$ or waist circumference ${ }^{(39,48-50)}$. In order to assess the effect of oats on body weight, it is necessary to also consider the energy and macronutrient content of the intervention diets, which is beyond the scope of the present review. Whilst oats may be used to displace other (more energy dense) foods in the diet, their effect on hunger and satiety is not clear. Although three ${ }^{(48,67,86)}$ of the studies included in the present review found no significant effect of oats on satiety, hunger or appetite, positive comments from one study ${ }^{(48)}$ included 'feeling more full, for longer' and 'less peaks \& lows' in intake. However, satiety is an acute physiological effect of a single meal intake and does not necessarily equate to longer-term changes in dietary habits, which could result in weight loss and/or reduced weight gain. Therefore, the measurement of satiety cannot substitute for longer-term intervention studies measuring body weight and/or composition. The European Food Safety Authority Panel on Dietetic Products, Nutrition and Allergies (NDA) recently concluded that a cause-and-effect relationship has not been established between the consumption of $\beta$-glucans from oats and barley and a sustained increase in satiety leading to a reduction in energy intake ${ }^{(100)}$. However, this aspect requires further investigation.

Whilst advice to increase oat consumption is likely to have beneficial health effects, it should be noted that relatively minor side effects (which may only be initial or intermittent) may include flatulence ${ }^{(15,43,57,59,85)}$, abdominal distension or bloating $^{(20,43,57,68,73)}$, diarrhoea or loose stools ${ }^{(35,57,68)}$, and abdominal pain or cramping ${ }^{(48,57)}$. Taking such side effects into consideration, one study ${ }^{(43)}$ found that $50 \mathrm{~g} / \mathrm{d}$ of oat bran was considered 'acceptable long term' by $76 \%$ of participants and 'unacceptable long term' by $24 \%$ of participants. 
Table 4. Results of studies assessing the effect of oat consumption on blood pressure

\begin{tabular}{|c|c|c|c|}
\hline \multirow[b]{2}{*}{ Comparison } & \multicolumn{2}{|c|}{ Blood pressure } & \multirow[b]{2}{*}{ Reference } \\
\hline & Systolic & Diastolic & \\
\hline \multicolumn{4}{|l|}{$<30$ subjects in the oat intervention group and low reporting quality } \\
\hline Oat bran $v$. wheat bran ( $20 \mathrm{~g}$ fibre) & NS & NS & Abrahamsson et al. ${ }^{(15)}$ \\
\hline $65 \mathrm{~g} / 8368 \mathrm{~kJ} / \mathrm{d}(2000 \mathrm{kcal} / \mathrm{d})$ oat bran bread v. $454 \mathrm{~g} / \mathrm{d}$ strawberries & NS & NS & Jenkins et al. ${ }^{(25)}$ \\
\hline $\begin{array}{l}\text { Oat bran, oatmeal and oat } \beta \text {-glucan } v \text {. wheat-based, low-fibre } \\
\text { cereal and maltodextrin powder }\end{array}$ & NS & NS & Maki et al. ${ }^{(35)}$ \\
\hline $45 \mathrm{~g} / \mathrm{d}$ oats $v$. without $45 \mathrm{~g} / \mathrm{d}$ oats & $4 \%^{*} \downarrow$ & NS & Saltzman et al. ${ }^{(41)}$ \\
\hline \multicolumn{4}{|l|}{$<30$ subjects in the oat intervention group and high reporting quality } \\
\hline Oatmeal and oat bran $v$. wheat-based cereal & NS & NS & Davy et al. ${ }^{(50)}$ \\
\hline $137 \mathrm{~g} / \mathrm{d}$ oat cereal $v .146 \mathrm{~g} / \mathrm{d}$ low-fibre cereal & $6 \% \%^{*} \downarrow$ & NS & Keenan et al. ${ }^{(55)}$ \\
\hline $95 \mathrm{~g} / \mathrm{d}$ oat bran $v .35 \mathrm{~g} / \mathrm{d}$ wheat bran & NS & NS & Kestin et al. ${ }^{(56)}$ \\
\hline $95 \mathrm{~g} / \mathrm{d}$ oat bran $v .60 \mathrm{~g} / \mathrm{d}$ rice bran & NS & NS & \\
\hline $100 \mathrm{~g} / \mathrm{d}$ oat bran $v$. refined wheat & NS & NS & Swain et al. ${ }^{(57)}$ \\
\hline $50 \mathrm{~g} / \mathrm{d}$ oat bran $v$. baseline & NS & NS & Uusitupa et al. ${ }^{(59)}$ \\
\hline \multicolumn{4}{|l|}{$30-59$ subjects in the oat intervention group and low reporting quality } \\
\hline 0 v. 30 v. 60 v. $90 \mathrm{~g} / \mathrm{d}$ oat bran & NS & NS & Leadbetter et al. ${ }^{(61)}$ \\
\hline $55 \mathrm{~g}$ high-fibre oat bran $v$. run-in & NS & NS & Mackay \& Ball ${ }^{(62)}$ \\
\hline $55 \mathrm{~g}$ low-fibre oat bran $v$. run-in & NS & NS & \\
\hline$\geq 50 \mathrm{~g} / \mathrm{d}$ Oat bran crispies $v$. no oat cereal & NS & NS & Poulter et al. ${ }^{(63)}$ \\
\hline $57 \mathrm{~g} / \mathrm{d}$ instant oats $v$. usual intake & NS & NS & Van Horn et al. ${ }^{(64)}$ \\
\hline \multicolumn{4}{|l|}{$30-59$ subjects in the oat intervention group and high reporting quality } \\
\hline Oats (high) $v$. oats, rice and wheat (low) $v$. corn, rice and wheat & NS & - & Charlton et al. ${ }^{(66)}$ \\
\hline $\mathrm{OBC}$ and Oatmeal Squares $v$. refined wheat and cornflakes & NS & NS & He et al. ${ }^{(67)}$ \\
\hline $60 \mathrm{~g} / \mathrm{d}$ uncooked whole oats $v$. baseline & NS & NS & Katz et al. ${ }^{(72)}$ \\
\hline $60 \mathrm{~g} / \mathrm{d}$ oat bran $v$. baseline & NS & NS & Lepre \& Crane ${ }^{(73)}$ \\
\hline Oat milk deprived of insoluble fibre $v$. rice milk & NS & NS & Onning et al. ${ }^{(7)}$ \\
\hline Oatmeal and Oat Squares $v$. wheat cereal and Kellogg's Crispix & $4 \%^{*} \downarrow$ & NS & Pins et al. ${ }^{(75)}$ \\
\hline Oats/soya and oats/milk v. wheat/soya and wheat/milk & NS & NS & Van Horn et al. ${ }^{(78)}$ \\
\hline \multicolumn{4}{|l|}{$\geq 60$ subjects in the oat intervention group and low reporting quality } \\
\hline $80 \mathrm{~g} / \mathrm{d}$ oat cereal $v$. low-fibre foods & NS & NS & Maki et al. ${ }^{(82)}$ \\
\hline Whole-wheat foods and oats $v$. whole-wheat foods & NS & NS & Tighe et al. ${ }^{(7)}$ \\
\hline $100 \mathrm{~g} / \mathrm{d}$ oatmeal $v$. wheat noodles & NS & NS & Zhang et al. ${ }^{(84)}$ \\
\hline \multicolumn{4}{|l|}{$\geq 60$ subjects in the oat intervention group and high reporting quality } \\
\hline $90 \mathrm{~g}$ oat cereal $v$. cornflakes & NS & NS & Johnston et al. ${ }^{(85)}$ \\
\hline $20 \mathrm{~g} / \mathrm{d}$ oat bran cereal $v .21 \mathrm{~g} / \mathrm{d}$ wheat bran cereal & NS & NS & Wolever et al. ${ }^{(88)}$ \\
\hline
\end{tabular}

OBC, oat bran concentrate.

*\% change from baseline relative to comparison group estimated.

\section{Limitations}

The majority of studies identified by the present review were relatively small and did not have sufficient power to detect an effect: only twenty-three of the seventy-six articles reviewed (30\%) described carrying out a sample size or power calculation. For many of the variables (such as total cholesterol, LDL-cholesterol, ICAM1, apo and glucose), variation among individuals has been found by other authors to be about 10-20\%. Baseline covariate adjustment should reduce this to 5-10\%. This means that sixty subjects per group should give sufficient experimental power (90\%) to detect intervention effects of $5-7 \%$. Even less variation is expected in total cholesterol (SD approximately $0.25 \mathrm{~mm}$, range 5-6 mm), so that sixty subjects per group will provide sufficient power to detect differences of $0.2 \mathrm{~mm}$. Larger sample sizes would be required to assess intervention effects on blood pressure and inflammatory markers.

Ideally, a meta-analysis would be carried out to assess whether oats have a significant effect on the outcomes reported in the present review, and if so the size of this effect. However, the authors concluded that a meaningful summary estimate could not be obtained by meta-analysis for several reasons. First, the studies were too heterogeneous. The amount and type of oat products used were varied, and the comparison/control groups included a range of different treatments, for example, refined wheat, whole-wheat products, rice bran, psyllium, farina, fruit or no control. The duration of the studies (from 2 weeks to 6 months) and the initial blood cholesterol concentration of the subjects were also varied. Secondly, many studies were considered of poor quality: $61 \%$ of articles had a low modified Jadad score, and $59 \%$ of studies had less than thirty subjects in the oat intervention group. Thirdly, the outcomes were reported inconsistently among studies, e.g. mean absolute difference, or percentage change, or simply a line in the text to say that there was no significant effect. Some changes were compared with a control group $v$. baseline, and some results were adjusted for confounding factors whereas others were not.

Furthermore, the present review did not consider the appropriateness of the control group, changes in body weight, energy intake and macronutrient intake during the intervention, or compliance with the intervention - all of which could impact the response to the intervention and thus a meta-analysis summary estimate. The question regarding what could be considered as an ideal control group is 
Table 5. Results of studies assessing the effect of oat consumption on glucose and insulin

\begin{tabular}{|c|c|c|c|}
\hline Comparison & Glucose & Insulin & Reference \\
\hline \multicolumn{4}{|l|}{$<30$ subjects in the oat intervention group and low reporting quality } \\
\hline Oat bran $v$. wheat bran ( $20 \mathrm{~g}$ fibre) & NS & NS & Abrahamsson et al. ${ }^{(15)}$ \\
\hline $100 \mathrm{~g} / \mathrm{d}$ oat bran $v$. control diet & NS & - & Anderson et al. ${ }^{(16)}$ \\
\hline Oat bran bread $v$. wheat bran bread & NS & NS & Bremer et al. ${ }^{(20)}$ \\
\hline $40 \mathrm{~g} / \mathrm{d}$ oat bran diet $v$. low-fibre diet $v$. & - & NS & Dubois et al. ${ }^{(23)}$ \\
\hline $100 \mathrm{~g} / \mathrm{d}$ oat bran $v$. no oat bran & NS & - & Kirby et al. ${ }^{(30)}$ \\
\hline $\begin{array}{l}\text { Oat bran, oatmeal and oat } \beta \text {-glucan } v \text {. wheat-based, } \\
\text { low-fibre cereal and maltodextrin powder }\end{array}$ & NS & NS & Maki et al. ${ }^{(35)}$ \\
\hline $87-121 \mathrm{~g} / \mathrm{d}$ oat bran $v .50-74 \mathrm{~g} / \mathrm{d}$ high-amylose starch diet & NS & NS & Noakes et al. ${ }^{(37)}$ \\
\hline $87-121 \mathrm{~g} / \mathrm{d}$ oat bran $v$. low-amylose starch diet & $3 \% * \uparrow$ & NS & \\
\hline $0 \cdot 75-1 \mathrm{l} / \mathrm{d}$ oat milk $v$. cow's milk & NS & NS & Onning et al. $^{(38)}$ \\
\hline $0.75-1 \mathrm{l} / \mathrm{d}$ oat milk $v$. soya milk & NS & NS & \\
\hline $45 \mathrm{~g} / \mathrm{d}$ oats $v$. without $45 \mathrm{~g} / \mathrm{d}$ oats & NS & NS & Saltzman et al. ${ }^{(41)}$ \\
\hline $123 \mathrm{~g} / \mathrm{d}$ oat bran $v .54 \mathrm{~g} / \mathrm{d}$ wheat bran & NS & - & Whyte et al. ${ }^{(46)}$ \\
\hline \multicolumn{4}{|l|}{$\begin{array}{l}<30 \text { subjects in the oat intervention group and } \\
\text { high reporting quality }\end{array}$} \\
\hline $\begin{array}{r}5-6 \mathrm{~g} / \mathrm{d} \text { oat bran } \beta \text {-glucan } v .8-9 \mathrm{~g} / \mathrm{d} \text { oat bran } \\
\beta \text {-glucan } v \text {. high fibre, no oat bran } \beta \text {-glucan }\end{array}$ & NS & NS & Beck et al. ${ }^{(48)}$ \\
\hline Oatmeal and oat bran $v$. wheat-based cereal & NS & NS & Davy et al. ${ }^{(49,50)}$ \\
\hline $60 \mathrm{~g} / \mathrm{d}$ oat cookies $v$. baseline & NS & NS & Conceicao de Oliveira et al. ${ }^{(51)}$ \\
\hline $60 \mathrm{~g} / \mathrm{d}$ oat cookies $v .300 \mathrm{~g} / \mathrm{d}$ fruit & $5 \% * \uparrow$ & - & \\
\hline $\begin{array}{l}\text { High molecular weight oat bran } \\
v \text {. baseline }\end{array}$ & $3 \%$ * $\downarrow$ & $23 \% * \uparrow$ & Frank et al. ${ }^{(52)}$ \\
\hline $\begin{array}{l}\text { Low molecular weight oat bran } \\
v \text {. baseline }\end{array}$ & NS & NS & \\
\hline $137 \mathrm{~g} / \mathrm{d}$ oat cereal $v .146 \mathrm{~g} / \mathrm{d}$ low-fibre cereal & - & NS & Keenan et al. ${ }^{(55)}$ \\
\hline $95 \mathrm{~g} / \mathrm{d}$ oat bran $v .35 \mathrm{~g} / \mathrm{d}$ wheat bran & NS & NS & Kestin et al. ${ }^{(56)}$ \\
\hline $95 \mathrm{~g} / \mathrm{d}$ oat bran $v .60 \mathrm{~g} / \mathrm{d}$ rice bran & NS & NS & \\
\hline $50 / d$ oat bran $v$. baseline & $+4 \%$ $\uparrow$ & NS & Uusitupa et al..$^{(59)}$ \\
\hline \multicolumn{4}{|l|}{$\begin{array}{l}\text { 30-59 subjects in the oat intervention group and } \\
\text { low reporting quality }\end{array}$} \\
\hline \multirow{2}{*}{\multicolumn{4}{|c|}{$\begin{array}{l}\text { No studies } \\
\text { 30-59 subjects in the oat intervention group and } \\
\text { high reporting quality }\end{array}$}} \\
\hline & & & \\
\hline $\begin{array}{l}\text { Oats (high) } v \text {. oats, rice and wheat (low) } \\
v \text {. corn, rice and wheat }\end{array}$ & NS & NS & Charlton et al. ${ }^{(66)}$ \\
\hline $\begin{array}{l}\text { Oat milk deprived of insoluble } \\
\text { fibre } v \text {. rice milk }\end{array}$ & NS & - & Onning et al. ${ }^{(74)}$ \\
\hline \multicolumn{4}{|l|}{$\begin{array}{l}\geq 60 \text { subjects in the oat intervention group and } \\
\text { low reporting quality }\end{array}$} \\
\hline $\begin{array}{l}\text { Whole wheat foods and oats } \\
v \text {. whole wheat foods }\end{array}$ & NS & NS & Tighe et al. ${ }^{(7)}$ \\
\hline $100 \mathrm{~g} / \mathrm{d}$ oatmeal $v$. wheat noodles & NS & - & Zhang et al. ${ }^{(84)}$ \\
\hline \multicolumn{4}{|l|}{$\begin{array}{l}\geq 60 \text { subjects in the oat intervention group and } \\
\text { high reporting quality }\end{array}$} \\
\hline $20 \mathrm{~g} / \mathrm{d}$ oat bran cereal $v .21 \mathrm{~g} / \mathrm{d}$ wheat bran cereal & NS & - & Wolever et al. ${ }^{(88)}$ \\
\hline
\end{tabular}

$* \%$ change from baseline relative to comparison group estimated.

important, and depends on the study aim as well as the primary outcomes of the trial. The results tables highlight the disparity of control groups used as comparators in previous studies. Guar gum, undefined control diet, usual diet, wheat- or rice-based products, $\beta$-glucan-enriched products as well as products based on specific parts of the grain such as bran and not the whole-grain product have been used. Some designs involved increasing total whole-grain intake without substitution of existing dietary components. An ideal control group should at least consider unchanged total energy intake during the intervention, substituting wholegrain food items with a similar amount of refined cereal products (white breads, etc.). The level of oats/whole-grain intake in the control group should match the lowest quartile of consumption observed in the population studied.
When trials aim to identify the active parts or components of the grain, a positive control (with whole grain) should also be included. Further analysis of the studies reviewed herein is required before sufficiently homogenous studies can be chosen for inclusion in a meta-analysis to obtain both a precise and meaningful estimate of the magnitude of the effect of oat consumption on CVD risk markers.

The lack of significant effects in some studies may have been due to the factors mentioned earlier, or could be due to the fact that the response may be modified by other factors. Some studies carried out sub-group analysis or tested for interaction (effect modification), e.g. by sex ${ }^{(29,37,38,52,83)}$, sex and age group ${ }^{(86)}$, BMI group ${ }^{(35)}$, ethnicity (Caucasians $v$. non-Caucasians) ${ }^{(89)}$, genotype ${ }^{(59,69)}$, amount of target dose consumed $^{(59)}$ and baseline total cholesterol level ${ }^{(40,83)}$. 
The results of such analyses were not considered in the present review; however, these need to be further assessed in larger studies with sufficient power for subgroup analyses or assessing effect modification.

The present review only considered the effect of oats on fasting lipids, glucose and insulin. However, regular consumption of oats may alter the postprandial concentrations. For example, Anderson et al. ${ }^{(18)}$ showed that $110 \mathrm{~g} / \mathrm{d}$ oat bran for $21 \mathrm{~d}$ significantly lowered postprandial serum total cholesterol and TAG concentrations $v$. a control diet. However, Kirby et $a l .{ }^{(30)}$ found that a similar amount of oat bran $(100 \mathrm{~g} / \mathrm{d})$ for a shorter time period (at least $10 \mathrm{~d}$ ) did not significantly affect postprandial serum total cholesterol or TAG, when measured at hourly intervals throughout the day when compared with a control diet. A 12-week trial of oat consumption significantly lowered the mean peak insulin and incremental area under the insulin curve response (both by $7 \%$ ) compared with a control group, but there was no significant change in peak glucose or incremental area under the glucose curve ${ }^{(35)}$. Other studies found that oats or oat bran did not significantly affect postprandial glucose or insulin responses ${ }^{(30,34,56)}$. The efficacy of oats and barley products to lower postprandial blood glucose concentration has been reviewed recently ${ }^{(13)}$. The author concluded that intact grain, as well as barley and oat products containing at least $4 \mathrm{~g}$ of $\beta$-glucan and $30-80 \mathrm{~g}$ of available carbohydrate can significantly reduce postprandial glucose concentrations. The health benefit of reducing postprandial glycaemia is still debatable, but a statement recently issued by the European Food Safety Authority indicates that 'the reduction of postprandial glycaemic responses (as long as insulinaemic responses are not disproportionally increased) may be a beneficial physiological effect ${ }^{(100)}$.

\section{Conclusions}

Regular consumption of oats or oat bran has a beneficial effect on total cholesterol and LDL-cholesterol, particularly in hypercholesterolaemic subjects. The intervention trials described in the present review can generally be divided into three groups depending on the product used in the intervention: oat bran; whole-grain oat cereals; oatmeal. For the studies that showed a significant reduction in total cholesterol and/or LDL-cholesterol, the range of doses used was $25-135 \mathrm{~g} / \mathrm{d}$ for oat bran, $45-90 \mathrm{~g} / \mathrm{d}$ for whole-grain oat cereals and $60-150 \mathrm{~g} / \mathrm{d}$ for oatmeal. So it appears that the form of oats does not really affect the outcome. The doses required to reach a significant effect were also similar. However, studies using amounts below $50 \mathrm{~g} / \mathrm{d}$ are scarce, and more welldesigned dose-response studies are needed to confirm the minimum amount required to have a clinical beneficial effect. The 3-6\% cholesterol reduction described in the larger studies would translate to a $6-18 \%$ decrease in CHD risk. Some studies reported significant effects on blood cholesterol only 2 weeks after beginning the intervention, so it is likely that the benefits of increasing oats intake start very shortly after changing the diet. How long these effects on blood cholesterol remain if subjects revert to their original diet remains to be determined. However, there is no indication that it would significantly modulate insulin sensitivity. It is still unclear whether increased oat consumption would significantly affect other risk markers for CVD risk. More comprehensive, properly controlled intervention trials with adequate sample sizes are required to answer this question. The present review also highlighted the heterogeneity of treatments used as a control and notes the importance of carefully defining appropriately controlled interventions.

\section{Supplementary material}

To view supplementary material for this article, please visit http://dx.doi.org/10.1017/S0007114514002281

\section{Acknowledgements}

The authors thank M. Mowett for sourcing the majority of the articles. F. T. reviewed articles for inclusion and drafted the paper. L. F. M. carried out the literature search, extracted the data and contributed to writing the paper, P. B. and P. K.-E. contributed to writing the paper.

F. T., P. K.-E. and P. B. received an honorarium from Quaker Oats Company (a subsidiary of PepsiCo) for attending the workshop in May 2012 to discuss the content of the supplement and the University of Aberdeen received an unrestricted grant from Quaker Oats Company. L. F. M. has no conflict of interest to report.

This paper was published as part of a supplement to British Journal of Nutrition, publication of which was supported by an unrestricted educational grant from Quaker Oats Co. (a subsidiary of PepsiCo Inc.). The papers included in this supplement were invited by the Guest Editor and have undergone the standard journal formal review process. They may be cited.

The Guest Editor to this supplement is Roger Clemens. The Guest Editor declares no conflict of interest.

\section{References}

1. Jacobs DRJ, Meyer KA, Kushi LH, et al. (1998) Whole-grain intake may reduce the risk of ischemic heart disease death in postmenopausal women: the Iowa Women's Health Study. Am J Clin Nutr 68, 248-257.

2. Liu S, Stampfer MJ, Hu FB, et al. (1999) Whole-grain consumption and risk of coronary heart disease: results from the Nurses' Health Study. Am J Clin Nutr 70, 412-419.

3. Whelton SP, Hyre AD, Pedersen B, et al. (2005) Effect of dietary fiber intake on blood pressure: a meta-analysis of randomized, controlled clinical trials. J Hypertens 23, 475-481.

4. Salmerón J, Manson JE, Stampfer MJ, et al. (1997) Dietary fiber, glycemic load, and risk of non-insulin-dependent diabetes mellitus in women. JAMA 277, 472-477.

5. Meyer KA, Kushi LH, Jacobs DRJ, et al. (2000) Carbohydrates, dietary fiber, and incident type 2 diabetes in older women. Am J Clin Nutr 71, 921-930.

6. Anderson JW \& Hanna TJ (1999) Impact of nondigestible carbohydrates on serum lipoproteins and risk for cardiovascular disease. J Nutr 129, Suppl. 7, 1457S-1466S. 
7. Tighe P, Duthie G, Vaughan N, et al. (2010) Effect of increased consumption of whole-grain foods on blood pressure and other cardiovascular risk markers in healthy middle-aged persons: a randomized controlled trial. Am J Clin Nutr 92, 733-740.

8. Anderson JW (2003) Whole grains protect against atherosclerotic cardiovascular disease. Proc Nutr Soc 62, 135-142.

9. Marckmann P, Sandström B \& Jespersen J (1994) Low-fat, high-fiber diet favorably affects several independent risk markers of ischemic heart disease: observations on blood lipids, coagulation, and fibrinolysis from a trial of middleaged Danes. Am J Clin Nutr 59, 935-939.

10. King DE, Egan BM \& Geesey ME (2003) Relation of dietary fat and fiber to elevation of C-reactive protein. Am J Cardiol 92, 1335-1339.

11. Brownlee IA, Moore C, Chatfield M, et al. (2010) Markers of cardiovascular risk are not changed by increased whole-grain intake: the WHOLEheart study, a randomised, controlled dietary intervention. Br J Nutr 104, 125-134.

12. Anderson JW (1995) Cholesterol-lowering effects of soluble fiber in humans. In Dietary Fiber in Health and Disease, pp. 126-145 [D Kritchevsky and C Bonfield, editors]. St Paul, MN: Eagan Press.

13. Tosh SM (2013) Review of human studies investigating the post-prandial blood-glucose lowering ability of oat and barley food products. Eur J Clin Nutr 67, 310-317.

14. Halpern SH and Douglas MJ (editors) Appendix: Jadad scale for reporting randomized controlled trials. In (2005, 2007) Evidence-Based Obstetric Anesthesia, pp. 237-238. Blackwell Publishing Ltd., Oxford, UK.

15. Abrahamsson L, Goranzon H, Karlstrom B, et al. (1994) Metabolic effects of oat bran and wheat bran in healthy women. Scand J Nutr Naringsforsk 38, 5-10.

16. Anderson JW, Story L, Sieling B, et al. (1984) Hypocholesterolemic effects of oat-bran or bean intake for hypercholesterolemic men. Am J Clin Nutr $\mathbf{4 0}$, $1146-1155$

17. Anderson JW, Spencer DB, Hamilton CC, et al. (1990) Oatbran cereal lowers serum total and LDL cholesterol in hypercholesterolemic men. Am J Clin Nutr 52, 495-499.

18. Anderson JW, Gilinsky NH, Deakins DA, et al. (1991) Lipid responses of hypercholesterolemic men to oat-bran and wheat-bran intake. Am J Clin Nutr 54, 678-683.

19. Bridges SR, Anderson JW, Deakins DA, et al. (1992) Oat bran increases serum acetate of hypercholesterolemic men. Am J Clin Nutr 56, 455-459.

20. Bremer JM, Scott RS \& Lintott CJ (1991) Oat bran and cholesterol reduction: evidence against specific effect. Aust N Z J Med 21, 422-426.

21. Davidson MH, Dugan LD, Burns JH, et al. (1991) The hypocholesterolemic effects of beta-glucan in oatmeal and oat bran. A dose-controlled study. JAMA 265, 1833-1839.

22. Demark-Wahnefried W, Bowering J \& Cohen PS (1990) Reduced serum cholesterol with dietary change using fatmodified and oat bran supplemented diets. I Am Diet Assoc 90, 223-229.

23. Dubois C, Armand M, Senft M, et al. (1995) Chronic oat bran intake alters postprandial lipemia and lipoproteins in healthy adults. Am J Clin Nutr 61, 325-333.

24. Hegsted M, Windhauser MM, Morris SK, et al. (1993) Stabilized rice bran and oat bran lower cholesterol in humans. Nutr Res 13, 387-398.

25. Jenkins DJ, Nguyen TH, Kendall CW, et al. (2008) The effect of strawberries in a cholesterol-lowering dietary portfolio. Metabolism 57, 1636-1644.
26. Judd PA \& Truswell S (1981) The effect of rolled oats on blood lipids and fecal steroid excretion in man. Am J Clin Nutr 34, 2061-2067.

27. Kahn RF, Davidson KW, Garner J, et al. (1990) Oat bran supplementation for elevated serum cholesterol. Fam Pract Res J 10, 37-46.

28. Kelley MJ, Hoover-Plow J, Nichols-Bernhard JF, et al. (1994) Oat bran lowers total and low-density lipoprotein cholesterol but not lipoprotein(a) in exercising adults with borderline hypercholesterolemia. I Am Diet Assoc 94, 1419-1421.

29. Kerckhoffs DA, Hornstra G \& Mensink RP (2003) Cholesterol-lowering effect of beta-glucan from oat bran in mildly hypercholesterolemic subjects may decrease when beta-glucan is incorporated into bread and cookies. Am J Clin Nutr 78, 221-227.

30. Kirby RW, Anderson JW, Sieling B, et al. (1981) Oat-bran intake selectively lowers serum low-density lipoprotein cholesterol concentrations of hypercholesterolemic men. Am J Clin Nutr 34, 824-829.

31. Kretsch MJ, Crawford L \& Calloway DH (1979) Some aspects of bile acid and urobilinogen excretion and fecal eliminiation in men given a rural Guatemalan diet and egg formulas with and without added oat bran. Am J Clin Nutr 32, 1492-1496.

32. Calloway DH \& Kretsch MJ (1978) Protein and energy utilization in men given a rural Guatemalan diet and egg formulas with and without added oat bran. Am J Clin Nutr 31, 1118-1126.

33. Kristensen M \& Bugel S (2011) A diet rich in oat bran improves blood lipids and hemostatic factors, and reduces apparent energy digestibility in young healthy volunteers. Eur J Clin Nutr 65, 1053-1058.

34. Maki KC, Davidson MH, Witchger MS, et al. (2007) Effects of high-fiber oat and wheat cereals on postprandial glucose and lipid responses in healthy men. Int J Vit Nutr Res $\mathbf{7 7}$, 347-356

35. Maki KC, Galant R, Samuel P, et al. (2007) Effects of consuming foods containing oat beta-glucan on blood pressure, carbohydrate metabolism and biomarkers of oxidative stress in men and women with elevated blood pressure. Eur J Clin Nutr 61, 786-795.

36. Marlett JA, Hosig KB, Vollendorf NW, et al. (1994) Mechanism of serum cholesterol reduction by oat bran. Hepatology 20, 1450-1457.

37. Noakes M, Clifton PM, Nestel PJ, et al. (1996) Effect of high-amylose starch and oat bran on metabolic variables and bowel function in subjects with hypertriglyceridemia. Am J Clin Nutr 64, 944-951.

38. Onning G, Akesson B, Oste R, et al. (1998) Effects of consumption of oat milk, soya milk, or cow's milk on plasma lipids and antioxidative capacity in healthy subjects. Ann Nutr Metab 42, 211-220.

39. Robitaille J, Fontaine-Bisson B, Couture P, et al. (2005) Effect of an oat bran-rich supplement on the metabolic profile of overweight premenopausal women. Ann Nutr Metab 49, 141-148.

40. Romero AL, Romero JE, Galaviz S, et al. (1998) Cookies enriched with psyllium or oat bran lower plasma LDL cholesterol in normal and hypercholesterolemic men from Northern Mexico. J Am Coll Nutr 17, 601-608.

41. Saltzman E, Das SK, Lichtenstein AH, et al. (2001) An oatcontaining hypocaloric diet reduces systolic blood pressure and improves lipid profile beyond effects of weight loss in men and women. $J$ Nutr 131, 1465-1470. 
42. Spiller GA, Farquhar JW, Gates JE, et al. (1991) Guar gum and plasma cholesterol. Effect of guar gum and an oat fiber source on plasma lipoproteins and cholesterol in hypercholesterolemic adults. Arterioscler Thromb 11, 1204-1208.

43. Stewart FM, Neutze JM \& Newsome-White R (1992) The addition of oatbran to a low fat diet has no effect on lipid values in hypercholesterolaemic subjects. $N Z$ Med J 105, 398-400.

44. Sturtzel B, Dietrich A, Wagner KH, et al. (2010) The status of vitamins $\mathrm{B}_{6}, \mathrm{~B}_{12}$, folate, and of homocysteine in geriatric home residents receiving laxatives or dietary fiber. $J$ Nutr Health Aging 14, 219-223.

45. Turnbull WH \& Leeds AR (1987) Reduction of total and LDL-cholesterol in plasma by rolled oats. J Clin Nutr Gastroenterol 2, 177-181.

46. Whyte JL, McArthur R, Topping D, et al. (1992) Oat bran lowers plasma cholesterol levels in mildly hypercholesterolemic men. J Am Diet Assoc 92, 446-449.

47. Zhang JX, Hallmans G, Andersson H, et al. (1992) Effect of oat bran on plasma cholesterol and bile acid excretion in nine subjects with ileostomies. Am J Clin Nutr 56, 99-105.

48. Beck EJ, Tapsell LC, Batterham MJ, et al. (2010) Oat betaglucan supplementation does not enhance the effectiveness of an energy-restricted diet in overweight women. BrJ Nutr 103, 1212-1222.

49. Davy BM, Davy KP, Ho RC, et al. (2002) High-fiber oat cereal compared with wheat cereal consumption favorably alters LDL-cholesterol subclass and particle numbers in middle-aged and older men. Am J Clin Nutr 76, 351-358.

50. Davy BM, Melby CL, Beske SD, et al. (2002) Oat consumption does not affect resting casual and ambulatory 24-h arterial blood pressure in men with high-normal blood pressure to stage I hypertension. J Nutr 132, 394-398.

51. Conceicao de Oliveira M, Sichieri R \& Sanchez Moura A (2003) Weight loss associated with a daily intake of three apples or three pears among overweight women. Nutrition 19, 253-256.

52. Frank J, Sundberg B, Kamal-Eldin A, et al. (2004) Yeastleavened oat breads with high or low molecular weight beta-glucan do not differ in their effects on blood concentrations of lipids, insulin, or glucose in humans. J Nutr 134, 1384-1388.

53. Gerhardt AL \& Gallo NB (1998) Full-fat rice bran and oat bran similarly reduce hypercholesterolemia in humans. J Nutr 128, 865-869.

54. Gold KV \& Davidson DM (1988) Oat bran as a cholesterolreducing dietary adjunct in a young, healthy population. West J Med 148, 299-302.

55. Keenan JM, Pins JJ, Frazel C, et al. (2002) Oat ingestion reduces systolic and diastolic blood pressure in patients with mild or borderline hypertension: a pilot trial. J Fam Pract 51, 369.

56. Kestin M, Moss R, Clifton PM, et al. (1990) Comparative effects of three cereal brans on plasma lipids, blood pressure, and glucose metabolism in mildly hypercholesterolemic men. Am J Clin Nutr 52, 661-666.

57. Swain JF, Rouse IL, Curley CB, et al. (1990) Comparison of the effects of oat bran and low-fiber wheat on serum lipoprotein levels and blood pressure. $N$ Engl J Med 322, $147-152$.

58. Uusitupa MI, Miettinen TA, Sarkkinen ES, et al. (1997) Lathosterol and other non-cholesterol sterols during treatment of hypercholesterolaemia with beta-glucan-rich oat bran. Eur J Clin Nutr 51, 607-611.
59. Uusitupa MI, Ruuskanen E, Makinen E, et al. (1992) A controlled study on the effect of beta-glucan-rich oat bran on serum lipids in hypercholesterolemic subjects: relation to apolipoprotein E phenotype. J Am Coll Nutr 11, 651-659.

60. Kemppainen T, Heikkinen M, Ristikankare M, et al. (2009) Effect of unkilned and large amounts of oats on nutritional state of celiac patients in remission. e-SPEN 4, e30-e34.

61. Leadbetter J, Ball MJ \& Mann JI (1991) Effects of increasing quantities of oat bran in hypercholesterolemic people. Am J Clin Nutr 54, 841-845.

62. Mackay S \& Ball MJ (1992) Do beans and oat bran add to the effectiveness of a low-fat diet? Eur J Clin Nutr $\mathbf{4 6}$, 641-648.

63. Poulter N, Chang CL, Cuff A, et al. (1994) Lipid profiles after the daily consumption of an oat-based cereal: a controlled crossover trial. Am J Clin Nutr 59, 66-69.

64. Van Horn L, Moag-Stahlberg A, Liu KA, et al. (1991) Effects on serum lipids of adding instant oats to usual American diets. Am J Public Health 81, 183-188.

65. Winblad I, Joensuu T \& Korpela H (1995) Effect of oat bran supplemented diet on hypercholesterolaemia. Scand J Prim Health Care 13, 118-121.

66. Charlton KE, Tapsell LC, Batterham MJ, et al. (2012) Effect of 6 weeks' consumption of $\beta$-glucan-rich oat products on cholesterol levels in mildly hypercholesterolaemic overweight adults. Br J Nutr 107, 1037-1047.

67. He J, Streiffer RH, Muntner P, et al. (2004) Effect of dietary fiber intake on blood pressure: a randomized, doubleblind, placebo-controlled trial. J Hypertens 22, 73-80.

68. Kashtan H, Stern HS, Jenkins DJ, et al. (1992) Wheat-bran and oat-bran supplements' effects on blood lipids and lipoproteins. Am J Clin Nutr 55, 976-980.

69. Hegele RA, Zahariadis G, Jenkins AL, et al. (1993) Genetic variation associated with differences in the response of plasma apolipoprotein B levels to dietary fibre. Clin Sci 85, 269-275.

70. Katz DL, Nawaz H, Boukhalil J, et al. (2001) Effects of oat and wheat cereals on endothelial response. Prev Med 33, 476-484.

71. Katz DL, Evans MA, Chan W, et al. (2004) Oats, antioxidants and endothelial function in overweight, dyslipidemic adults. J Am Coll Nutr 23, 397-403.

72. Katz DL, Evans MA, Nawaz $\mathrm{H}$, et al. (2005) Egg consumption and endothelial function: a randomized controlled crossover trial. Int J Cardiol 99, 65-70.

73. Lepre F \& Crane S (1992) Effect of oatbran on mild hyperlipidaemia. Med J Aust 157, 305-308.

74. Onning G, Wallmark A, Persson M, et al. (1999) Consumption of oat milk for 5 weeks lowers serum cholesterol and LDL cholesterol in free-living men with moderate hypercholesterolemia. Ann Nutr Metab 43, 301-309.

75. Pins JJ, Geleva D, Keenan JM, et al. (2002) Do whole-grain oat cereals reduce the need for antihypertensive medications and improve blood pressure control? J Fam Pract 51, 353-359.

76. Theuwissen E \& Mensink RP (2007) Simultaneous intake of beta-glucan and plant stanol esters affects lipid metabolism in slightly hypercholesterolemic subjects. J Nutr 137, $583-588$.

77. Theuwissen E, Plat J \& Mensink RP (2009) Consumption of oat beta-glucan with or without plant stanols did not influence inflammatory markers in hypercholesterolemic subjects. Mol Nutr Food Res 53, 370-376. 
78. Van Horn L, Liu K, Gerber J, et al. (2001) Oats and soy in lipid-lowering diets for women with hypercholesterolemia: is there synergy? J Am Diet Assoc 101, 1319-1325.

79. Berg A, Konig D, Deibert P, et al. (2003) Effect of an oat bran enriched diet on the atherogenic lipid profile in patients with an increased coronary heart disease risk. A controlled randomized lifestyle intervention study. Ann Nutr Metab 47, 306-311.

80. Karmally W, Montez MG, Palmas W, et al. (2005) Cholesterol-lowering benefits of oat-containing cereal in Hispanic Americans. J Am Diet Assoc 105, 967-970.

81. Keenan JM, Wenz JB, Ripsin CM, et al. (1992) A clinical trial of oat bran and niacin in the treatment of hyperlipidemia. J Fam Pract 34, 313-319.

82. Maki KC, Beiseigel JM, Jonnalagadda SS, et al. (2010) Whole-grain ready-to-eat oat cereal, as part of a dietary program for weight loss, reduces low-density lipoprotein cholesterol in adults with overweight and obesity more than a dietary program including low-fiber control foods. J Am Diet Assoc 110, 205-214.

83. Van Horn L, Emidy LA, Liu KA, et al. (1988) Serum lipid response to a fat-modified, oatmeal-enhanced diet. Prev Med 17, 377-386.

84. Zhang J, Li L, Song P, et al. (2012) Randomized controlled trial of oatmeal consumption versus noodle consumption on blood lipids of urban Chinese adults with hypercholesterolemia. Nutr J 11, 54.

85. Johnston 1, Reynolds HR, Patz M, et al. (1998) Cholesterollowering benefits of a whole grain oat ready-to-eat cereal. Nutr Clin Care 1, 6-12.

86. Keenan JM, Wenz JB, Myers S, et al. (1991) Randomized, controlled, crossover trial of oat bran in hypercholesterolemic subjects. J Fam Pract 33, 600-608.

87. Van Horn LV, Liu K, Parker D, et al. (1986) Serum lipid response to oat product intake with a fat-modified diet. J Am Diet Assoc 86, 759-764.

88. Wolever TM, Tosh SM, Gibbs AL, et al. (2010) Physicochemical properties of oat $\beta$-glucan influence its ability to reduce serum LDL cholesterol in humans: a randomized clinical trial. Am J Clin Nutr 92, 723-732.

89. Wolever TM, Gibbs AL, Brand-Miller J, et al. (2011) Bioactive oat $\beta$-glucan reduces LDL cholesterol in Caucasians and non-Caucasians. Nutr J 10, 130.

90. Ripsin CM, Keenan JM, Jacobs DRJ, et al. (1992) Oat products and lipid lowering. A meta-analysis. JAMA 267, $3317-3325$
91. National Cholesterol Education Program (NCEP) Expert Panel on Detection, Evaluation, and Treatment of High Blood Cholesterol in Adults (Adult Treatment Panel III) (2002) Third Report of the National Cholesterol Education Program (NCEP) Expert Panel on Detection, Evaluation, and Treatment of High Blood Cholesterol in Adults (Adult Treatment Panel III) final report. Circulation 106, 3143-3421.

92. Superko HR \& Gadesam RR (2008) Is it LDL particle size or number that correlates with risk for cardiovascular disease? Curr Atheroscler Rep 10, 377-385.

93. Barr EL, Zimmet PZ, Welborn TA, et al. (2007) Risk of cardiovascular and all-cause mortality in individuals with diabetes mellitus, impaired fasting glucose, and impaired glucose tolerance: the Australian Diabetes, Obesity, and Lifestyle Study (AusDiab). Circulation 116, 151-157.

94. Pearson TA, Mensah GA, Alexander RW, et al. (2003) Markers of inflammation and cardiovascular disease: application to clinical and public health practice: a statement for healthcare professionals from the Centers for Disease Control and Prevention and the American Heart Association. Circulation 107, 499-511.

95. Ajani UA, Ford ES \& Mokdad AH (2004) Dietary fiber and C-reactive protein: findings from national health and nutrition examination survey data. J Nutr 134, 1181-1185.

96. Ma Y, Griffith JA, Chasan-Taber L, et al. (2006) Association between dietary fiber and serum C-reactive protein. $A m \mathrm{~J}$ Clin Nutr 83, 760-766.

97. Selhub J (2008) Public health significance of elevated homocysteine. Food Nutr Bull 29, Suppl. 2, S116-S125.

98. Raiko JR, Oikonen M, Wendelin-Saarenhovi M, et al. (2012) Plasminogen activator inhibitor-1 associates with cardiovascular risk factors in healthy young adults in the Cardiovascular Risk in Young Finns Study. Atherosclerosis 224, 208-212.

99. Noto D, Barbagallo CM, Cefalu' AB, et al. (2002) Factor VII activity is an independent predictor of cardiovascular mortality in elderly women of a Sicilian population: results of an 11-year follow-up. Thromb Haemost 87, 206-210.

100. European Food Safety Authority (2011) Scientific Opinion on the substantiation of health claims related to betaglucans from oats and barley and maintenance of normal blood LDL-cholesterol concentrations (ID 1236, 1299), increase in satiety leading to a reduction in energy intake (ID 851, 852), reduction of post-prandial glycaemic responses (ID 821, 824), and "digestive function" (ID 850) pursuant to Article 13(1) of Regulation (EC) No. 1924/ 2006. EFSA J 9, 2207-2228. 